\title{
Checkerboard Grid: Go and Chinese Chess_-Urban Planning and Political Ideologies in American Westward Movement and Ancient China
}

\author{
Shaoqian Zhang \\ Department of Art, Graphic Design and Art History, Oklahoma State University, Stillwater, USA \\ Email: shaoqian.zhang@okstate.edu \\ Received September $7^{\text {th }}$, 2013; revised October $7^{\text {th }}$, 2013; accepted October $15^{\text {th }}, 2013$
}

Copyright (c) 2013 Shaoqian Zhang. This is an open access article distributed under the Creative Commons Attribution License, which permits unrestricted use, distribution, and reproduction in any medium, provided the original work is properly cited.

\begin{abstract}
Among all forms of city planning, the grid plan appears, historically, to be the most measurable and recognizable system of civic geography. This paper will explore how and why different social groups have been able to define the symbolism of the grid to suit their own political purposes and how governments and patrons have utilized the grid as the spatial manifestation for their political ideologies. This paper will be based on case studies of cities operating under very dissimilar political systems, i.e., the cities of ancient China and the city of Chicago in the Unites States. I argue that the American grid plan focuses on its peripheries, and that the expansive instinct of the American grid was effective in building a coherent American nation, transcending regional and class divisions. By contrast, the Chinese grid plan emphasizes the center, and the practices of urban planning in ancient China symbolized the evaluative tactics of the elite.
\end{abstract}

Keywords: Grid Plan; Government Politics; Traditional Chinese Philosophy; Capital City; Chicago

\section{Introduction}

City planning is the deployment of the political machine and its symbolic localization. A planned city can be both receptacle and representation of social relationships. Ordering the landscape by subdividing its geography into rational parts aims toward efficiency of administration, communication and political persuasion. Among all forms of city planning, the grid plan seems to be the most recognizable and measurable. Everyone can recognize the checkerboard grid, which is "like a great geometrical carpet, like a Mondrian painting” (Stilgoe, 2004: p. 5). A grid subdivides a continent into repeated graph squares on paper and it appears to be simply a triumph of the mathematic and scientific art.

However, it is safe to suggest that nobody has fully understood the grid as city planning, even though this way of planning mathematically is nothing new and particular. The fascination with geometry and the grid has been applied around the world, in ancient China and throughout the Roman Empire. The implication of the grid plan is manifold. "The grid's mythic power," as Krauss wrote, "is that it makes us able to think we are dealing with materialism (or sometimes science, or logic) while at the same time it provides us with a release into belief (or illusion, or fiction)" (Krauss, 1985: p. 12). The grid has the function of making one see for oneself rather than being something ideal and materialistic in and of itself. Its simple and seemingly universal form gives rise to different political ideologies and powers.

In an attempt to engage these issues, this paper will explore how and why different social groups are able to define the symbol of grid to suit their own political purposes; how governments and patrons utilize the grid as the spatial manifestation for their political ideologies. This paper will be based on case studies of cities of different political systems, ancient Chinese cities and Chicago in the Unites States. Attention will be given to applications of grid plans, which define the space of cities, and even essence of nations differently.

\section{America}

The grid, with its mathematical equality and indifference to variations, makes it very easy to lay out new towns before settlement. The grid was first applied to America by colonists and then by Americans themselves, in an effort to control the vast landscape. In 1784, Jefferson was appointed by the Continental Congress to be in charge of a committee to devise a plan for the temporary government of the Western territory. Jefferson devised the rectangular survey as a way of simplifying real estate transactions. Soon it was enacted into law and divided the land west of the original thirteen colonies into an orthogonal grid of 36-square-mile townships; each in turn was divided into onemile square sections.

As observed by American architecture historian, John W. Reps, the indiscriminate application of the square grid of the 1785 Land Survey to the entire Western territory of the United States was a logical expression of practicality, establishing control over the land with the greatest degree of speed, efficiency, and potential interest (Reps, 1965). The grid proved reasonably effective in ordering the land for sale and settlement. It made it easy to describe rectangular parcels of land on maps, 
so that speculators could buy and sell them sight unseen. In addition to its mathematical regularity, it was "flexible, with plenty of room for variety within and between the presumably anonymous blocks” (Reps, 1965: p. 267). Space was counted in order to be occupied. The grid was a versatile planning model and open to expansion once planned. It used a hydraulic model, as opposed to the stable, the eternal and the constant.

Almost all cities, towns, and villages planned after the turn of the $18^{\text {th }}$ century reflected an underlying grid in their physical appearance. Chicago unexceptionally accepted the expression of Jefferson's grid. Chicago had two dominant natural features: the expanse of Lake Michigan, which stretches, unbroken by islands to the horizon; and a corresponding area of land extending north, west, and south without hills or any marked elevation. Its lack of geographic features made it highly suitable for a grid plan. The effects of the city were obtained by repetition of the unit. Even though the shape of the city was a little irregular; the perpendicular pattern remained and became crucial for the city's expansion. A map from 1830 by James Thompson contributed much to the ultimate shape and personality of the future metropolis. Additions to the city over the last century extended the grid pattern established in the original plan. A map of 1834 exhibited Chicago's first real estate development. The Kinzie Addition began from the north of the Chicago river and east of State Street; the Wolcott Addition was along the North Branch of the Chicago river. As the West began to grow prodigiously, overland routes multiplied and stimulated the growth of the city. The stimulus to Chicago's growth also came from the eastern transportation facilities to the city (Mayer \& Wade, 1965: pp. 24-25). The city’s framework, the grid of Chicago, was compatible with the commercial activities, manufacture and transportation.

The Loop was not only the physical symbol of Chicago's commercial power, but also the engine of the city's expansion. Concentrated with the Loop were many commercial skyscrapers, government buildings and offices, new department stores and the leading civic cultural institutions. The old boundaries of the Loop could no longer contain the growing population and burgeoning commerce. Commercial facilities expanded from the center of the city, forcing residential construction to move to the edge of the town and into the suburbs beyond. Real estate investors were busy due to the urban development and they settled into new suburban areas. The grid plan was applied during this urban expansion. It was relatively easy to designate city streets by numbers rather than names, permitting fast growth of the city.

The fire of 1871 did not stop the growth of the city. By 1880 a new cycle of development was under way. Chicago solidified its position as industrial and commercial leader for the nation and adopted radical innovation in mass transit, which accelerated its horizontal expansion. The increased speed and efficiency of transportation permitted the vast expansion of the city beyond its earlier confines. Uncultivated land quickly fell to the developer and the framework of the grid. Chicago became an "exploding metropolis" as its grid swallowed up neighborhood areas (Mayer \& Wade, 1965: p. 144).

The great growth of the metropolis took place in the outer zones rather than central zones. Foreshadowed by Potter Palmer's move to Lake Shore Drive in the 1880s, the exodus from the center became a rush after 1893. Social elites were eager to escape from the congested city and shifted to the shore of Lake Michigan on the near north side. Thus, every year, many people were released from the centrally-located neighborhoods into the middle class areas. There areas occupied a wide belt around the densely inhabited residential and commercial core, thinning out toward the municipal limits and fading into nonurbanized areas. The outward expansion of the metropolis was not confined to residential development. The central city was too small and congested to accommodate the growth of manufacturing. Investors looked for undeveloped land close enough to the city yet far enough from downtown to be uncluttered and cheap (Mayer \& Wade, 1965: p. 186).

There seemed to be nothing to prevent Chicago from its rapid expansion and it was dubbed "the City of Speed" by Newton Dent of Munsey's Magazine. He wrote (Mayer \& Wade, 1965: p. 272) :

Nothing, that either man or nature can do, apparently, can check the growth this city that has spread back from the lake like a prairie fire, until its great bulk covers nearly two hundred square miles of Illinois (Mayer \& Wade, 1965: p. 272).

Chicago's grid became a "rhythm without measure" (Deleuze \& Guattari, 1987: p. 264), ready to occupy a non-varying space. Its keynote was expansion and its vitality lay in its indefinable periphery. As addressed by Daniel Burnham, "People in Chicago must recognize that their city is without bounds or limits" (Burnham \& Bennett, 1993: p. 80). Due to the characteristics of the grid, Chicago was territorialized and at the same time continually deterritorialized through the opening of frontiers and exodus. The grid was formed not only on the basis of its powers of accumulation and the city's extension, but also on the basis of its capacity to develop itself more deeply, to be reborn, and to extend itself throughout the latticework of society.

To go back to the starting point of Jefferson's grid, the grid on American frontier was not, however, strictly functional. Despite its seemingly practical mechanism, Jefferson's grid, as suggested by André Corboz, it reflected a certain ideology and religious outlook. André Corboz demonstrates in his article "Die kulturellen Grundlagen des territorialen Rasters in den USA" that among other things the American grid, which originnated in 1785 with Jefferson's Ordinance, must be a religious grid because it follows the same impetus as described in the last chapter of the Book of Ezekiel in the Old Testament-God plans Israel as the land of the future, the Promised Land-by dividing it up into perfectly equal parts among Israel's twelve tribes (Corboz, 2001: pp. 186-260) ${ }^{1}$. He does not intend to argue that Jefferson gridded America because he wanted to recreate what he had read in the Bible. The argument is about a certain mentality embedded in the nature of American grid which is related to the perception of the future. Jefferson saw a correlation between architecture, behavior, and belief. Architecture was understood by him as "a symbolic expression of a culture's ideals and achievements and as an instrument for intellectual and moral improvement.” For Jefferson, architecture should be a style appropriate for a democratic society and landscape should be cultivated properly.

In Jefferson's ideal version of America, independent farmer citizens who lived in simple cottages on their plots of land should occupy the vast landscape for the emerging nation of America (Kostof, 1987: p. 15). Living the life of a country

\footnotetext{
${ }^{1}$ I must thank Julia Ng for translating the German text for me.
} 
squire, he resented centralized urban control and dreamed of an agrarian America of small towns and farms where every man was his own master and the vast landscape belonged to all the people equally. His grid was intended to produce a context of equilibria and reduce complexities, enabling egalitarian citizenship. Frank Lloyd Wright restated this national faith in the 1930s in his Broadacre City, where citizens would be assigned to one acre of land so that they could exercise what he called man's "social right to his place on the ground" (Kostof, 1987: p. 16). Under the passionate belief of what architecture signified, Jefferson's grid subjected four-fifths of the United States to a regular system of land survey that speedily answered the needs of an agricultural economy and the conquest of the territories of the West and was greatly concerned with the theme of the frontier. Ownership of landscape encouraged more than a sense of independence. Divided up into squares, the land provoked a sensual hunger in later settlers and its own characteristics promoted its future expansion.

The principle of the grid was that it could be expanded without limit. It set norms because it proceeded from the land as an abstraction. Not until farmers settled the great rectangles platted by the surveyor did the lines become more than legal abstractions of boundaries. Grid run undisturbed over topography and climate change and gave concrete form to the principle of equality. The American grid finally expanded and reached the Pacific in 1910. Its victory lay in its ability to internalize the outside and swallow up differences. It projected an even surface without variation. The territory was understood by the grid to be pure and homogeneous extension without centers. It emphasized transportation and communication, as the exterior and interior were in competition and coexistence.

Each unit was always in relationship with an outside and was inconceivable outside that relationship. Its energy was in its frontier, where the interior met the exterior and was ready to capture the unknown territory. In American grid, it was a question arraying oneself in an open space, of holding space, of maintaining the possibility of springing up at any point and of consolidating the unknown territory by the construction of an adjacent territory. The grid presented itself as a diffuse spatial machine and produced movement toward expansion and submission.

\section{Ancient Chinese Grid}

The grid plan in China was continuous from the 15th BC onwards. Guidelines were put into written form in the chapters of Jiangren yingguo (Craftsmen Constructing the State) Zhouli Kaogong ji (Records of Craftsmen of Zhou Rituals) during the Spring and Autumn Period (770-476 BCE). This short paragraph imposed great influence on historic Chinese city planning theory:

When a jiangren constructs a state capital, he creates a square, nine $l i^{2}$ on each side and each side has three gates. In the capital city are nine north-south avenues and nine east-west streets. The avenues are nine carriage tracks wide. On the left is the ancestral temple and to the right is the altar of soil and grain. In the front is the court palace and behind the market (Steinhardt, 1990: p. 33).

Jiangren, literally a craftsman, could be properly translated

${ }^{2} \mathrm{Li}$ is a unit of length, close to the scale of a mile. as "an architect" in this context. Since the Han Dynasty (BCE 206), the social ideas had already taken root in the concept of architecture. City planners incorporated the political and hierarchical principles into the city planning. The ideal metropolis should be well organized and standardized according to the concept of universal principles. They believed that if they subdivided the city into grids, according to universal principles, the city would be gifted with the symbolic power of the universe. The squareness, the numerical series based on number three, the grid in relation to the four cardinal points, the implied domination of the north-south over the east-west orientation are the basic elements of an abstract pattern of intentional configuration of a capital city.

The universal principles were incorporated into many ancient Chinese cities' architectural layouts, even though not very strictly. For example, Chang'an was the capital of the Tang Dynasty (618-907) when China exhibited great strength, supported by a prosperous economy and strong military. The city was built rigidly symmetrical with the empire's palace right in the center of the northern section of the city. Chang'an was designed to meet the ruler's ideal and requirements for the governing. It was divided into wards made orderly with avenues running between them. Each ward was guarded by tall and heavy ward walls, which all together constituted the grid of the city.

The square shape, the repeated wards and the important palace position were all traditions from the ritual thoughts, which materialized the political authority of the emperor. First, as Records of Craftsmen of Zhou Rituals stipulated, palaces or a palace city should always be the theme of capital cities, standing out of the repeated units. Second, the capital city should be heavily guarded by layers of walls. All units were fenced by ward walls and the whole city was enclosed in the city walls. Walls in Chang'an not only guarded the city but also constituted the framework of the symbolic grid. Thus the grid in Chang'an was not expansive but restrained and self-defensive.

In the case of Beijing, the grid was not only the symbol, but also the instrument of the emperor's political power. The spatial strategies of the whole Beijing City was epitomized in the architectural layout of the Forbidden City, which was a large, horizontally expansive, architectural complex in a rectangular shape on a north-south axis, covering an area of about 723,600 square meters. It was the most sacred place in China for over five hundred years. The Forbidden City was constructed as the core structure of Beijing and the geo-political center of the empire. When it was planned, it was expected to be the focus of the symbolic presence of Chinese imperial power. Before the Opium War in 1840, the Forbidden City was heavily guarded and not accessible to commoners.

Gates and walls were two principal features of the Forbidden City in the past as they "shaped a city and made it meaningful" (Wu, 1991: p. 86). Gates allowed a procession path to penetrate the walls and linked separate parts into a continuum of space. Walls in the Forbidden City not only encircled spaces from the whole city down to repeated enclosures, but also, "dissected, internalized and deepened space” (Zhu, 2004: p. 24). The walls functioned as layers of barriers that repeatedly separated the inside from the outside. In other words, walls gridded the whole space while gates offered the circulation between different units of the grid. By deepening and segmenting the space, the emperor would be concealed and protected by layers of walls. Only high-rank officials, servants, people of the imperial house- 
hold and aristocrats, could reach the deep center of Beijing. The emperor's power was thus reinforced as the supreme arbiter by the invisibility of his privacy and the myth of his capability. The spatial strategies of the Forbidden City promoted an effective and automatic central control.

Zhu Jianfei, a well-known Chinese historian, likened the Forbidden City to Bentham's famous Panopticon proposal, which was a meticulously planned prison: "at the periphery, an annular building; at the center, a tower; this tower is pierced with the wide windows open onto the inner side of the ring" (Foucault, 1979: p. 157). Panopticon was used for surveillance as there was an inequality in the views of people in the annular building and the central tower. The criminals were in transparent prisons and under surveillance at all times. The institutional arrangement was established through the asymmetry between the inspector and the inspected.

The deepest and most invisible part of the Forbidden City was in the far north section, it was comparable to a half of the Panopticon. The northern end, where the emperor resided, was equivalent to the Panopicon's center power. In the deepest center, the emperor could deliver his message and decrees to his officers immediately. The communication between him and his officers was strictly one way. The emperor obtained a panoramic gaze on his subjects and his country from above. While there was a gaze upon the outside, there was no visibility to the court from the outside. The major effect of the Panopticon was to induce in the inmate a state of the conscious and permanent visibility that assures the automatic functioning of power. Similarly, the Forbidden City was also an apparatus of inducing consciousness of power, a space inscribed with the network of discipline.

The network of discipline was promoted by the grid of the Forbidden City. The hierarchical grid promoted the subjects' consciousness of social orders and persuaded them to employ the rules of society to police themselves. Similar to the Forbidden City, the city of Beijing also displayed a centrality, symmetry and hierarchal spatial layout in its overall composition. Different from Chang'an, where the imperial city was in the very north, Beijing exhibited a three-walled city style. At the center of the grid was the palace city, namely the Forbidden City for the emperor and royal family. The next box was the imperial city, which was an extension of the palace city. It included royal gardens, altars, residential areas of noble families. The largest enclosure was the capital city, which housed other urban populations. There was an outer city attached to the capital city. The outer city was the most secular place in Beijing where commercial activities were vibrant. Inside these urban boxes or grids, city planners also subdivided the space into small squares.

A hierarchy of center and periphery was represented in the city planning of Beijing, sustaining a social and political order. In the disposition of the City of Beijing, horizontal depth correlated to vertical height within the social hierarchy: the deeper one was in the center of the city, the higher the position of that person. In terms of Beijing geographic space, it was largely a grid; while in terms of its social space, it resembled strictly a pyramid. The sacred imperial ideologies were represented as hierarchical disposition revealing an effective political domination. The grid in Beijing created islands and urban blocks, articulating differences in social position. It related the geographic space to social space rather than promoting expansion.

As demonstrated by Chinese art historian, Wu Hung, "the difference between imperial Beijing and its remote ancestor is not its structure but its infinite horizontal expansion: walls and gates were added and the central axis was elongated” (Wu, 1991: p. 87). For Wu Hung, temporary changes in city planning were less significant than spatial stability and its elaborate complexity as a whole. The reason why a culture would insistently reject any fundamental change from the tradition in city planning was rooted in the long lasting social orders through Chinese history. The architectural structure paralleled the social structure closely. As there was a hierarchical structure in society, there was a hierarchical grid in city planning. The ancient Chinese grid turned out to be the preventive mechanism, the mechanism necessary to enable the emperor to become the supreme ruler of the country.

\section{Conclusion}

To summarize, the American used grid as a means of understanding the border region as potential or actual site of occupation; the ancient Chinese understood it as universal discipline and hierarchy. For Chinese, strategic geographical thinking usually proved more important than mathematical accuracy. In other words, mathematical accuracy was less important than a strategic understanding of the land for a bio-geographic control. Obedient human bodies were located in the city block within the network of the grid. For Jefferson, with the expansive grid was the fusing mechanism allowing expansion into the American West. With the mathematical accuracy of the grid, the western landscape was informed by a realistic, scientific way of viewing the land. It was self-consciously seen as having the potential to assist in the expansion of political ideologies into the new territories.

Jefferson's anti-urban ideology was comparable to anti-elite nationalism. In his influential 1893 essay The Significance of the Frontier in American History, Frederick Jackson Turner identified this point. He associated individualistic and egalitarian qualities with the frontier spirit: "The frontier promoted the formation of a composite nationality for the American people... In the crucible of the frontier the immigrants were Americanized, liberated, and fused into a mixed race” (Linklater, 2002: p. 174). As a result, frontier people had a sense of themselves as democratically inclined even though they might be deeply divided by different regional identities along class lines. "The rise of democracy was an effective force in the nation,” Turner asserted, "... and it meant the triumph of the frontier" (Linklater, 2002: p. 175). Despite its inherent inaccuracies pointed out by later historians and geographers, Turner's remarks pointed out that the expansive instinct of American grid was effective in building a coherent American nation that transcended the regional and class divisions.

In contrast, the practices of urban planning in ancient China symbolized the evaluative tactics of the elite. The hierarchical grid was shaped within the most homogenized, traditional and centralized socio-political elite ideologies of ancient China. The underlying ideas of Records of Craftsmen of Zhou Rituals resembled the principles of Zhou Li (Rituals of Zhou):

It is the sovereign alone who establishes the states of the empire, gives to the four quarters their proper positions, gives to the capital its form and to the fields their proper divisions. He creates the offices and apportions their functions in order to form a centre to which people may look (Wright, 1997: pp. 45-47). 
The emperor of ancient China was the architect who designed his political map and the mechanism of walling off spaces. The idea of a nation was a centralized one, historically personalized in the emperor himself. Thus the idea of nationalism was essentially a concept confined to the emperor and those educated elites around him. The masses were the object of the nation rather than the subject of the nation. After all, the grid was but one of many traditions invented by political elites in an attempt to legitimize their rule. Elite nationalism and centralized grid became insufficient only when the political and economic penetration of imperialistic powers reached such an extent that a mass movement was required to counter it. For the ancient Chinese grid, it was a question of arranging within oneself not accumulating for oneself.

If one compares the nation apparatus in the context of the theory of checkerboard games, Chinese chess and Go, the relationship between repeated units and the overall strategies concerned, Chinese grid was like Chinese chess. Chinese chess pieces have eternal qualities: a king remains a king and a solider remains a solider. They are "coded; they have an internal nature and intrinsic properties from which their movements, situations and confrontations derive... Each is like a subject of the statement endowed with a relative power, and these relative powers combine in a subject of enunciation” (Deleuze \& Felix Guattari, 1987: p. 352). The coded chess pieces move within their "striated" landscape (Deleuze \& Felix Guattari, 1987: p. 353). Their functions are structural and protecting the emperor in the center. American grid evoked the strategies of Go. Go pieces were deprived of all personalities and characteristics. They are anonymous, collective and nomadic, moving on a “smooth" space (Deleuze \& Felix Guattari, 1987: p. 353). They only have an environment of the exterior so they look for the possibility of holding their own space and springing up at any point and direction.

As addressed by Gilles Deleuze in his treatise on the war machine: "The difference is that chess codes and decodes space, whereas Go proceeds altogether differently, territorializing or deterritorializing it... it seems that every morning, there are more of [their pieces]" (Deleuze \& Felix Guattari, 1987: pp. 351-352). On the politically inscribed landscapes, while China emphasized the interior, America emphasized externalization as its overall space increased in size. Ancient China epitomized the idea of the nation being comprised of a few elites while America constructed its nationalism by fusing the masses through the grid system. If the geographically non-varying landscape is a metaphor for a nation, the different notions of grid plans mirror different approaches of constructing national- ism and cultivating people.

\section{REFERENCES}

Ames, R. T. (1994). The art of rulership: A study of ancient Chinese political thought. Albany: State University of New York Press.

Bernard, M. B. (1977). Architectural practice in America, 1865-1965Ideal and Reality. In: Kostof, S. (Ed.), The architect: Chapters in the history of the profession. New York: Oxford University Press.

Burnham, D. H., \& Bennett, E. H. (1993) Plan of Chicago. New York: Princeton Architectural Press.

Corboz, A. (2001). Die kulturellen grundlagen des territorialen rasters in den USA. In Die kunst, stadt und land zum sprechen zu bringen (pp. 186-200). Basel: Birkhäuser.

Deleuze, G., \& Guattari, F. (1987). A thousand plateaus: Capitalism and schizophrenia. Minneapolis: University of Minnesota Press.

Foucault, M. (1979). Discipline \& punish, the birth of prison. New York: Random House.

Hildegard, B. J. (1976). Order upon land: The U.S. rectangular land survey and the Upper Mississippi Country. London: Oxford University Press.

Kostof, S. (1987). America by design. New York: Oxford University Press.

Linklater, A. (2002). Measuring America: How an untamed wilderness shaped the United States and fulfilled the promise of democracy. New York: Walker \& Company.

MacDougall, E. B. (1990). The architectural historian in America: Studies in the history of art. Washington DC: National Gallery Art.

Mayer, H. M., \& Wade, R. C. (1969). Chicago: Growth of a metropolis. Chicago: The University of Chicago Press.

Reps, J. W. (1965). Making American landscape. Princeton: Princeton University Press.

Reps, J. W. (1970). The forgotten frontier: Urban planning in the American west before 1890. Princeton: Princeton University Press.

Reps, J. W. (1970). Town planning in frontier America. Princeton: Princeton University Press.

Steinhardt, N. S. (1990). Chinese imperial city planning. Honolulu: University of Hawaii Press.

Stilgoe, J. R. (2004). National design: Mercantile cities and the grid. In: Eggener, K. L. (Ed.), American architectural history: A contemporary reader. London and New York: Routledge.

Wright, A. F. (1997). The cosmology of the Chinese City. In: W. G. Skinner (Ed.), The City in Late Imperial China, Redwood City: Stanford University Press.

Wu, H. (1991). Tiananmen square: A political history of monuments. Representations, 35, 84-117. http://dx.doi.org/10.1525/rep.1991.35.1.99p00662

Zhao, S. S. (2004). A nation-state by construction: Dynamics of modern Chinese nationalism. Redwood City: Stanford University Press.

Zhu, J. F. (2004). Chinese spatial strategies: Imperial Beijing 14201911. London and New York: Routledge Curzon. 